\title{
Study on the Potential of Hyperaccumulator Leersia hexandra swartz to Repair Chromium Contamination of Heavy Metals
}

\author{
Zhiyi Lin ${ }^{1,2}$, Hua Lin ${ }^{1,2}$,Yian Wang ${ }^{1,2}$ and Yuhang Yuan ${ }^{1,2}$ \\ ${ }^{1}$ Guangxi Key Laboratory of Environmental Pollution Control Theory and Technology, Guilin University of Technology, Guilin, China \\ ${ }^{2}$ Collaborative Innovation Center for Water Pollution Control and Water Safety in Karst Area, Guilin University of Technology, Guilin, \\ China
}

\begin{abstract}
In order to control the environmental pollution caused by chromium better, this paper summaries the study about the accumulation charac-teristics, tolerance mechanism,detoxification mechanism and enrichment efficiency of chromium in Leersia hexandra swartz in recent years. It concluded that Leersia hexandra swartz has considerable potential for remediation of polluted environment, especially large-area, low-concentration polluted water, and prospects of its future research direction.
\end{abstract}

\section{Introduction}

Commonly henvy metal pollution mainly refers to $\mathrm{Pb}$, $\mathrm{Hg}, \mathrm{Cd}, \mathrm{As}, \mathrm{Cr}$ and other heavy metals that cause great ecological and health risks to animals, plants and humans[1], among which chromium is a color-silver metal, insoluble in nitric acid and water. Chromium can be dissolved in sulfuric acid to form salts, and chromium is a source of great environmental pollution[2]. In addition, chromium and its compounds are important industrial raw materials, and are mostly used in electroplating, printing and dyeing industries. These industries all generate chromium wastewater discharge, causing serious chrome water pollution[3]. For example, in 2009, chromium pollution drinking well water event in Shuangfeng county of Loudi, Hunan province, and large area of water pollution caused by chromium pollution in Qujing,Yunnan in 2011 have greatly affected the local drinking water. Moreover, chromium is a recognized teratogenic and carcinogenic substance[4-6]. In China, the first "Twelfth Five-Year" special plan"The 12th five-year plan for integrated prevention and control of heavy metals pollution" lists chromium as one of the five key prevention and control elements; chromium (VI) is placed in the United States Environmental Protection Agency. Chromium is listed as one of the 17 chemicals that are extremely harmful to the human body[7].

Therefore, chromium pollution treatment is particularly important, but the traditional methods of chromium pollution: adsorption, chemical reduction, ion exchange treatment methods generally have the problem that high processing costs, energy consumption, process complexity, and easy secondary pollution. Those problem limit the applications of traditional methods[810]. Discussion on how to adopt inexpensive, environment- friendly phytoremediation technology has become a hot topic[11].Phytoremediation uses special

a Corresponding author: linhua5894@163.com hyperaccumulators to transfer heavy metals that pollute the environment to roots and leaves of plants, then harvest the plants for restoration purposes[2]. Although there are many heavy metal hyperaccumulators at present, there are very few hyperaccumulators of chromium, only the foreign reports of Dicomaniccolifera and Sutera fodina, and the only wet plant found in China, which is currently reported.[12].

There are many reviews of phytoremediation[13-15], but still many restrictions on the use of phytoremediation for heavy metal pollution, such as the slow growth rate and growth of hyperaccumulators, the low transfer rate of heavy metals and the concentration of heavy metal pollution. All of those restrictions affect the phytoremediation efficiency and limits the practical application of phytoremediation [16]. Some studies have shown that the artificial wetland of Leersia hexandra swartz has good effect on the recovery of chromium (VI) exceeding 150 times $(7.50 \mathrm{mg} / \mathrm{L})$ water body[3], but the contribution of direct absorption and removal of chromium by Leersia hexandra swartz is less than $10 \%[17]$. How to improve the enrichment efficiency of the chromium-containing environmental pollution by Leersia hexandra swartz is the key to the application of Leersia hexandra swartz to the environment.

\section{The discovery of Leersia hexandra swartz}

The Leersia hexandra swartz is a wet plant of perennial grasses and is the only chromium hyperaccumulator found and reported in China[18]. In a wet environment, the rapid growth of Leersia hexandra swartz and the high density of the larvae make the biomass per unit area large, which improves the efficiency of the heavy metal polluted environment. At first, Leersia hexandra swartz was concerned as a kind of damage to rice weeds, and 
related agricultural scholars began to study it $[19,20]$; then it is found that the biological characteristics of Leersia hexandra swartz are drought tolerant and waterlogging tolerant, some scholars have explored their potential in areas of soil and water conservation and vegetation restoration[21,22]; because Leersia hexandra swartz also have good absorption effect on other heavy metals, so many scholars have also used Leersia hexandra swartz for the treatment of heavy metalcontaminated soils and constructed wetlands to remediate heavy-metal-contaminated water bodies and multiple heavy-metal mixed domestic sewage waters[2325]. In order to provide a theoretical basis for the restoration of large-scale, low-concentration polluted water bodies, this paper discusses recent studies on the chromium enrichment capacity of Leersia hexandra swartz and the influence of enrichment of chromium on Leersia hexandra swartz.

\section{Hyper-enrichment characteristics of chromium in Leersia hexandra swartz}

According to a study on the wet plant near an electroplating factory in northern Guangxi, it found that Leersia hexandra swartz has an ultra-enriched characteristic of chromium. The study found that the average content of chromium absorbed by leaves was $1787 \mathrm{mg} / \mathrm{L}$, the ratio of chromium content in leaves to in roots was 12 ; the ratio of chromium content in leaves to in soil was 57 and the ratio of chromium content in leaves to in water was 518[12]. Leersia hexandra swartz also has high removal rates for mixed pollutedwaters containing chromium, copper, and nickel. Table 1 shows the statistics of theremoval efficiency of chromium, copper, and nickel at different concentrations within 10 days of Leersia hexandra swartz [26].

Table 1. Heavy metal removaleffect statistics at different concentrations.

\begin{tabular}{|c|c|c|c|c|}
\hline \multirow{2}{*}{$\begin{array}{c}\text { Heavy } \\
\text { metal }\end{array}$} & $\begin{array}{c}\text { Initial } \\
\text { concentrati } \\
\text { on }(\mathrm{mg} / \mathrm{L})\end{array}$ & $\begin{array}{c}\text { First day } \\
\text { concentratio } \\
\mathbf{n}(\mathrm{mg} / \mathrm{L})\end{array}$ & $\begin{array}{c}\text { Sixth day } \\
\text { concentratio } \\
\mathbf{n}(\mathrm{mg} / \mathrm{L})\end{array}$ & $\begin{array}{c}\text { Tenth } \\
\text { Day } \\
\text { concent } \\
\text { ration } \\
(\mathrm{mg} / \mathrm{L})\end{array}$ \\
\hline \multirow{2}{*}{$\mathrm{Cr}$} & 10 & 3 & 0.9 & - \\
\cline { 2 - 6 } & 20 & 15 & 2.9 & - \\
\hline \multirow{2}{*}{$\mathrm{Cu}$} & 10 & 2.13 & 1 & 1.02 \\
\cline { 2 - 6 } & 20 & 5.2 & 3 & 1.25 \\
\hline \multirow{2}{*}{$\mathrm{Ni}$} & 10 & 7.8 & 1.9 & 1.3 \\
\cline { 2 - 6 } & 20 & 17 & 4.8 & 3.2 \\
\hline
\end{tabular}

spectrophotometer

In the restoration of heavy metal polluted waters containing chromium, copper and nickel, it state that Leersia hexandra swartz has good results. According to experiments, the highest removal rates of chromium, copper, and nickel havereached 100\% , 93.8\% , and $89.3 \%$ respectively. Leersia hexandra swartz can also enrich chromium, copper, and nickel in heavy metal- contaminated soils. Leersia hexandra swartz can still grow normally in soils with chromium, copper, and nickel contents of 8516,3442 , and $2992 \mathrm{mg} / \mathrm{kg}$. It has strong patience for soils contaminated by high concentrations of heavy metals [27]. This indicates that the species of Leersia hexandra swartz is valuable for research in the field of remediation of heavy metals contaminatedsoils or water bodies.

\section{The tolerance mechanism and detoxification mechanism of Leersia hexandra swartz}

Different metals have different biological activities, and the level of activity determines the plant's enrichment efficiency. Table 2 is an overview of the biologicalactivi -ty of plants on some metals[28].

Table 2. Bioactivity activity of plants on different metals

\begin{tabular}{|c|c|}
\hline Biological activity & Metal Category \\
\hline High & $\mathrm{Cd} 、 \mathrm{Ni} 、 \mathrm{Zn} 、 \mathrm{Se}$ \\
\hline $\mathrm{In}$ & $\mathrm{Mn} 、 \mathrm{Fe}$ \\
\hline low & $\mathrm{Pb} 、 \mathrm{Cr}$ \\
\hline
\end{tabular}

The previous article mentioned that phytoremediation technology uses special hyperaccumulateors to transfer heavy metals that pollute the environment to the roots and leaves of plants, and then harvest the plants for restoration purposes. It can be seen from Table 2 that chromium is of low biological activity, and some plants cannot transport them to above-ground parts after absorption, or the transport coefficient is very low, so the purpose of phytoremediation technology cannot be achieved. For example, about $80 \%$ of the chromium absorbed by Lycopersicon esculentum Mill is distributed in the root, and only a small portion can be transported to the aerial parts[29]. The enrichment of chromium in Leersia hexandra swartz can be represented by the content of chromium in each part of the tissue. Table 3 shows the average content of chromium in the each part of the tissue after absorbing the different concentrations of chromium[30].

Table 3. Leersia hexandra swartz distributed amount of absorption of different concentrations of chromium in vivo.

\begin{tabular}{|c|c|c|c|}
\hline \multirow{2}{*}{$\begin{array}{c}\text { Initial } \\
\text { concentration } \\
(\mathrm{mg} / \mathrm{L})\end{array}$} & \multicolumn{3}{|c|}{ Chromium content $(\mathrm{mg} / \mathrm{kg}$ DW) } \\
\cline { 2 - 4 } & root & stem & leaf \\
\hline 0 & 34.38 & 23.49 & 36.66 \\
\hline 5 & 993.4 & 335.7 & 891.4 \\
\hline 30 & 20253 & 930.4 & 4302 \\
\hline 60 & 33048 & 1486 & 2932 \\
\hline
\end{tabular}

From the bioconcentration factor (ratio of the absorption content of each part to the nutrient solution), the average values of the calculated roots, stems, and leaves were $474.86,123.52$, and 40.97 respectively. It can be seen that the Leersia hexandra swartz have a large capacity enrichment of chromium. characteristic. At the chromium concentrations of 5,30 and $60 \mathrm{mg} / \mathrm{L}$ the chromium transfer coefficient (ratio of leaf content to 
root content) is $90 \%, 1.24 \%$ and $9 \%$ respectively. It can be seen that with the increase of chromium concentration, the transfer coefficient of chromium is also greatly reduced, so the use of Leersia hexandra swartz to repair larg eareas, low concentrations of chromium polluted water worth studying. Many plants can survive in heavy metal-contaminated environments, the important point is the distribution of heavy metals in the body. Plants isolate the enriched heavy metals in highly resistant areas, avoiding toxic heavy metals damaging important tissues and organelles[31]. On the one hand, the vacuoles in the cell walls and leaves of the roots of the Leersia hexandra swartz were the main enrichment sites for chromium. When the chromium concentration increased, the Leersia hexandra swartz transferred the chromium from the roots to the upper leaves to separate them. From the roots segregation to leaves segregation is an important mechanism for the detoxification of chromium by Leersia hexandra swartz. On the other hand, under the heavy metal stress, a large amount of active oxygen in the plant will produce damage to the membrane structure, which is not conducive to the survival of the plant. The antioxidant enzymes SOD, POD, and CAT in plants can remove reactive oxygen species. Studies have shown that under the chromium stress, the contents of three enzymes of SOD, POD and CAT increase, which effectively alleviates the perforation of chromium to Leersia hexandra swartz[32]. Therefore, the antioxidant enzyme system plays an important role in the tolerance and detoxification of chromium in Leersia hexandra swartz.

\section{Effects of different exogenous substances on the enrichment of chromium in Leersia hexandra swartz}

In the process of accumulation of heavy metals, the existing hyperconcentration plants are affected by the soil and water in the complex environment. In practical application, only a small amount of heavy metals can be removed. Therefore, how to improve the efficiency of phytoremediation of heavy metals polluting environment is a hot topic in the field of environmental remediation research. Nitrogen and sulfur are essential nutrients for plants. Applying nitrogen fertilizer to Solanum nigrum promotes, promoted the growth of Solanum nigrum and increases the accumulation of $\mathrm{Cd}$ on Solanum nigrum [33]; appropriate amount of sodium sulfite is added to Leersia hexandra swartz, which promoted the accumulation of chromium in Leersia hexandra swartz and increased the chromium transport coefficient[34]. Adding exogenous substances to the essential nutrients of plants may be a means to increase the efficiency of plant enrichment. Leersia hexandra swartz has shown good ability to remove total nitrogen when treating wastewater containing heavy metals[35]. It can be considered that adding appropriate amount of nitrogen fertilizer to Leersia hexandra swartz can improve the enrichment of heavy metals when Leersia hexandra swartz repairing the environment.
Plants combine heavy metals with MT, PCs, GSH, organic acids, etc., but studies have found that the absorption of chromium by Leersia hexandra swartz is not related to the first three ways, it related to organic acids, and may be the coordination of oxalic acid with chromium in organic acids, and passivation to fix chromium in the body, and oxalic acid may be the main chelator of chromium in Leersia hexandra swartz leaf [36]. Plant oxalic acid has been considered as a metabolite with undefined physiological effects, but more and more studies have shown that oxalic acid plays an important role in plants adapting to environmental stress. For example, chromium in leaves of E.crassipes may form oxalate precipitation with oxalic acid[37], the $\mathrm{Zn}$ of $\mathrm{T}$. careulescens root is closely related to malic acid and oxalic acid[38]. Glyoxylic acid is a synthetic precursor of oxalic acid. Under chromium stress, adding a proper amount of glyoxylic acid to Leersia hexandra swartz not only promotes plant growth and chromium accumulation, but also effectively promotes the synthesis of oxalic acid[39]. Therefore, oxalic acid may be an effective mechanism for the enrichment and toleration of high concentrations of chromium in Leersia hexandra swartz. Shorter biomass and shorter growth cycle are the limiting factors for resource utilization of Leersia hexandra swartz. While we can effectively promote the biomass of Leersia hexandra swartz and heavy metal accumulation of Leersia hexandra swartz, we also need to promote the increase of the transport coefficient. Then harvest the plant can achieve the purpose of repairing contaminated soil and water bodies. The addition of exogenous substances, EDTA organic compounds, can strengthen the antioxidant enzyme system of Leersia hexandra swartz and promote the transfer of chromium from the root to the aerial parts[40].

\section{Outlook}

In addition to phytoremediation, microbiological restoration of chromium pollution has become a hot topic for researchers in recent years[41, 42]. This is a method of using a surface structure of microorganisms to adsorb heavy metals, or using microorganisms to produce reducing substances, enzyme catalytic systems etc., to convert chromium (VI) to chromium (III)[43]. Some scholars have also combined the two technologies to study, for example, inoculating Brassica juncea with Enterobacter aerogentes and Rahnella aquatilis with growth promoting characteristics can increase the absorption of chromium and nickel[44]. The combined microbiological-plant remediation technology takes advantage of phytoremediation (low cost, environmental friendliness, etc.), and increases plant enrichment efficiency and shortens repair cycles [45-47] and research shows that this technology has great potential for managing environmental pollution[48, 49]. Except for studying the addition of exogenous substances to improve the accumulation of heavy metals in Leersia hexandra swartz, the research on the joint repair technology of Leersia hexandra swartz and microbes is a very good research direction. 


\section{Acknowledgements}

Zhiyi Lin and Hua Lin contributed equally to this work, and Hua Lin is corresponding author (linhua5894@163.com). This work was funded by National Natural Science Foundation of China (No. 51608143).

\section{References}

1. W.L. Liu, Anhui Agricultural Sciences. (16): p. 4026-4027+4030 ( 2006 )

2. D. Li , X.F. Zhang, K. Huang, Z.G. Cheng, C. Tian, Anhui Agricultural Sciences. (06): p. 16711673+1794 ( 2014 )

3. Q.X. Wu, J. Liu, Z.J. Jin, S.H. You , Journal of Environmental Engineering. (02): p. 536-540 ( 2014 )

4. P. Miretzky A. Fernandez Cirelli, Journal of Hazardous Materials. 180(1-3): p. 1-19 ( 2010 )

5. Y.Z. Xu, X.N. Qin, X.h. Liu, N.X. Zhang, Y.L. Zhou, Environmental Science and Technology. (S1):p. 8-9 + 28 ( 2002 )

6. B.X. Zhou, D. Zhou, Chemical World. (02): p. 112 ( 2000 )

7. CE Barrera-Diaz, V. Lugo-Lugo, B. Bilyeu, Journal of Hazardous Materials. 223 : p. 1-12 ( 2012 )

8. W. Liu , Z.Q. Li, Guangdong Trace Elements Science. (09): p. 5-9 ( 2007 )

9. R.W. Xie, Ecological Science. (03): p. 285-288 ( 2006 )

10. L. Yang, C. Hu , Guangxi Light Industry. (07): p. 96-97 ( 2008 )

11. J.J. Tian, Phytoremediation and Toxic Effects of Cd Polluted Water (Jilin Agricultural University,2007)

12. X.H. Zhang, Y.P. Luo, H.T. Huang, J. Liu , Y.N. Zhu ,Journal of Ecology. (03): p. 950-953 ( 2006 )

13. W.X. He, X. Jiang, M.X. Zhu, F. Wang, Journal of Ecology. (03): p. 47-51+68 ( 2001 )

14. Y.M. Luo, Soil . (02): p. 57-61+74 ( 2000 )

15. A.F. Zhao, X. Zhao, X.L. Chang, Soil Bulletin. (01): p. $44-47+50$ ( 2000 )

16. T. Lebeau, A. Braud, K. Jezequel, Environmental Pollution. 153(3): p. 497-522（2008）

17. J. Liu, X.H. Zhang, S.H. You, Q.X. Wu, K.N. Zhou, Ecological Engineering. 81: p. 70-75 (2015)

18. X.H. Zhang, J. Liu, H.T. Huang, J. Chen, Y.N. Zhu, Chemosphere. 67 (6): p. 1138-1143 ( 2007 )

19. H.L. Liu, Y.X. Liu, J.Wei , X.L. Liu, S.M. Zhao, Tianjin Agricultural Sciences. (04):p. 38-40 ( 2000 )

20. L.Z. Yuan, F.Q. Zhou, Y. Geng, X.X. Kang, Y.F. Chen, modern agricultural science and technology. (07):p. 132-134 + 138 ( 2015 )

21. G.C. Zhu, tolerant plants (Leersiahexandra Research) of water stress physiological and ecological adaptation mechanisms (Sun Yat-sen, 2011)

22. G.C. Zhu , S.J. Gao , X. Zhang, Journal of Yangtze University ( Natural Science )Agricultural Science. (04): p. 52-55+129 ( 2010 )

23. K. Li, C.Gu , J. Liu,H.X. Huang, Y.H.Gao, Enviro nmental Science and Technology. (11): p. 151-155 (2014)

24. Q.X. Wu, J. Liu, S.H. You, K.N. Zhou, Journal of Environmental Sciences. (09): p. 2306-2312 ( 2014 )

25. X.H. Zhang, J.J. Sun, J. Liu, C. Hu , H.T. Huang, Anhui Agricultural Sciences. (13): p. 5586-5587 + 5590 ( 2008 )

26. J. Chen, D.Q. Wang, X.H. Zhang, J. Liu , Y.P. Liang, Agricultural Science environment. (04): p. 1514-1518 ( 2008 )

27. J. X. Tao, X.H. Zhang, H. Luo, J. Liu, Y.F. Liao, Guilin University of Technology. (01): p. 144-147 ( 2010 )

28. X.L. Li, Studies on ecological root exudates of cadmium hyperaccumulation in southeast Jingtian (Zhejiang University, 2011)

29. S. Srivastava, S. Prakash, M. M. Srivastava, Plant and Soil. 212(2): p. 203-208 ( 1999)

30. C. Hu, Research on the detoxification mechanism of chromium in Leersia hexandra swartz ( Guilin Institute of Technology, 2008)

31. S. D. Bidwell, S. A. Crawford, I. E. Woodrow, J. Sommer-Knudsen, A. T. Marshall, Plant Cell and Environment. 27(6): p. 705-716 (2004)

32. B. Huang, D. Zhang, Y. Li, X. Zhang, Z.B. Hao, Journal of Northeast Agricultural University. (01): $p$. 121-126 ( 2012 )

33. L. Wang, Q.X. Zhou, Y.B. Sun , Chinese Environmental Science. (10): p. 915-920 ( 2008 )

34. Z.G. Cheng, X.H. Zhang, X. F. Zhang, J. Liu , humic acid. (06): p. 50 ( 2017 )

35. L.L. Tan, Z.Z. Liu, M.N. Liang, C.K. Zhang, C. Xing, Environmental Science and Technology. (08): p. 138-141 ( 2014 )

36. X.H. Zhang, J. Liu, D. Wang, Y. Zhu, C. Hu, Bulletin of Environmental Contamination and Toxicology. 82(3): p. 358-362 (2009)

37. C. M. Lytle, F. W. Lytle, N. Yang, J. H. Qian, D. Hansen, Environmental Science \& Technology. 32(20): p. 3087-3093 (1998)

38. R. P. Tolra, C. Poschenrieder, J. Barcelo, Journal of Plant Nutrition. 19(12): p. 1541-1550 (1996)

39. W.P. Wang, H. Zhang, J. Liu, Y.Y. Lu, Safety and Environmental Engineering. (01): p. 12-16 ( 2014 )

40. Y. Yan, J.P. Li , Q.Y. Lin, Environmental Science and Technology. (07): p. 22-27 ( 2009 )

41. P. Lodeiro, A. Fuentes, R. Herrero, ME Sastre De Vicente, Environmental Chemistry. 5 (5): p. 355365 ( 2008 ) 
42. J. Wang C. Chen, Biotechnology Advances. 27(2): p. 195-226 (2009)

43. Z. Chen, Mechanism of interaction between $B$. cereus and heavy metal chromium ( Fujian Agriculture and Forestry University, 2010)

44. K. V. Kumar, S. Srivastava, N. Singh, H. M. Behl, Journal of Hazardous Materials. 170(1): p. 51-57 (2009)

45. Y. Ma, MNV Prasad, M. Rajkumar, H. Freitas, Biotechnology Advances. 29 (2): p. 248-258 ( 2011 )

46. L. Chen , C. Wang, X.Y. Hu , Q. Fan , Green Technology. (16): p. 10-12+15 ( 2016 )

47. H. Yao, X. F. Zhang, Z.S. Wu, Anhui Agricultural Sciences. (12):p. 68-70 ( 2016 )

48. B. R. Glick, Biotechnology Advances. 28(3): p. 367-374 (2010)

49. M. Rajkumar, S. Sandhya, M.N.V. Prasad, H. Freitas, Biotechnology Advances. 30 (6): p. 15621574 ( 2012 ) 